\title{
Correction: gene cluster analysis for the biosynthesis of elgicins, novel lantibiotics produced by Paenibacillus elgii B69
}

Yi Teng, Wenpeng Zhao, Chaodong Qian, Ou Li, Liang Zhu and Xuechang Wu*

\section{Correction}

It has come to our attention that we have used Asp, rather than the correct annotation of Asn, to indicate Asparagine throughout the text [1].

In the abstract this is corrected to: The $\mathrm{N}$-terminal sequence of elgicin B was Leu-Gly-Asn-Tyr, which corresponded to the partial sequence of the peptide ElgA encoded by $\operatorname{elg} A$.

In the Results section, subsection 'Analysis of Nterminal amino acid sequence', all instances of Asp should be replaced with Asn.

We regret any inconvenience that this inaccuracy in the text might have caused.

\section{Reference}

1. Yi T, Wenpeng Z, Chaodong Q, Ou L, Liang Z, Xuechang W: Gene cluster analysis for the biosynthesis of elgicins, novel lantibiotics produced by Paenibacillus elgii B69. BMC Microbiol 2012, 12:45.

* Correspondence: mblab@zju.edu.cn

Institute of Microbiology, College of Life Sciences, Zhejiang University, 866 Yuhangtang Road, Hangzhou 310058, P. R. China

Submit your next manuscript to BioMed Central and take full advantage of:

- Convenient online submission

- Thorough peer review

- No space constraints or color figure charges

- Immediate publication on acceptance

- Inclusion in PubMed, CAS, Scopus and Google Scholar

- Research which is freely available for redistribution

Submit your manuscript at www.biomedcentral.com/submit

C Biomed Central 